\title{
Erythrocyte sodium-lithium countertransport is not different in Type 1 (insulin-dependent) diabetic patients with and without diabetic nephropathy
}

\author{
L.D. Elving ${ }^{1}$, J.F.M. Wetzels ${ }^{2}$, E. de Nobel $^{1}$ and J.H.M.Berden ${ }^{2}$ \\ Department of Medicine, Divisions of ${ }^{1}$ General Internal Medicine and ${ }^{2}$ Nephrology, University Hospital, Nijmegen, The Netherlands
}

\begin{abstract}
Summary. We studied erythrocyte sodium-lithium countertransport in 33 patients with Type 1 (insulin-dependent) diabetes mellitus with diabetic nephropathy, 18 patients with Type 1 diabetes without diabetic nephropathy and in 42 nondiabetic patients with various other renal diseases. No significant differences were found in sodium-lithium countertransport between these three groups (median
\end{abstract}

(range) $322(162-676)$ vs 321 (189-627) vs 300 (142-655) $\mu \mathrm{mol}-1$ cells $\left.^{-1} \cdot \mathrm{h}^{-1}\right)$. We conclude, that sodium-lithium countertransport cannot be used as a marker for diabetic nephropathy.

Key words: Type 1 (insulin-dependent) diabetes mellitus, sodium-lithium countertransport, diabetic nephropathy.
Erythrocyte sodium-lithium countertransport (NaLiCT) is regarded as a marker for a predisposition to essential hypertension [1]. In non-diabetic parents of patients with diabetic nephropathy a higher prevalence of essential hypertension is found [2], suggesting a relationship between a familial predisposition to essential hypertension and the occurrence of diabetic nephropathy. Recently, it has been demonstrated that patients with diabetic nephropathy had higher levels of NaLiCT than diabetic patients without nephropathy $[3,4]$ and non-diabetic patients with other renal diseases [4]. These data suggested that NaLiCT could be a useful marker for diabetic nephropathy. We have measured NaLiCT in diabetic patients with and without nephropathy and in patients with non-diabetic renal diseases.

\section{Subjects and methods}

We studied three groups of Caucasian patients.

1. Eighteen patients with Type 1 diabetes mellitus for more than 15 years and without diabetic nephropathy (albumin excretion rate (AER) $<20 \mu \mathrm{g} / \mathrm{min}$ ).

2. Thirty-three patients with Type 1 diabetes mellitus with diabetic nephropathy $($ AER $>20 \mu \mathrm{g} / \mathrm{min}$; duration of diabetes $>10$ years; all patients had evidence of retinopathy).

3. Forty-two patients with various non-diabetic renal diseases.
All patients came to the out-patient clinic between 08.00 and 10.00 hours. A venous blood sample was drawn into two heparincontaining $10 \mathrm{ml}$ vacuum tubes and processed within $2 \mathrm{~h}$ for duplicate NaLiCT-measurement. A blood sample was also taken for measurement of serum creatinine and $\mathrm{HbA} \mathrm{A}_{1 \mathrm{c}}$. NaLiCT was measured according to the method described by Ibsen [5]. Briefly, erythrocytes were loaded with lithium in a $\mathrm{LiHCO}_{3^{-}}$ medium over 20 min resulting in an intracellular lithium concentration above the maximum transport capacity $\left(>5 \mathrm{mmol} \cdot 1 \mathrm{cells}^{-1}\right)$. Normal values for NaLiCT in our laboratory, obtained in 24 healthy subjects ( 9 males, 15 females; mean age $30 \pm 9$ years, range: $22-56$ years) varied from $134-390$ with a median value of $244 \mu \mathrm{mol} \cdot 1 \mathrm{cells}^{-1} \cdot \mathrm{h}^{-1}$. The intra-assay variation of the method is $5 \%$. The inter-assay variation, also representing the biological variability, is $13 \%$.

Of the diabetic patients albuminuria was measured in overnight timed urine samples using laser immunonephelometry [6]. In the patients with non-diabetic renal disease proteinuria was measured in a single urine sample using the biuret method and expressed per mmol of creatinine [7]. $\mathrm{HbA}_{1 \mathrm{c}}$ was measured by HPLC (normal value: $4.3-6.3 \%$ ). Blood pressure was measured using a standard mercury sphygmomanometer with the patients in supine position after 5 min rest. Hypertension was defined as a mean arterial pressure (MAP) $>110 \mathrm{mmHg}$ or the use of antihypertensive drugs.

\section{Statistical analysis}

All results are expressed as mean $\pm \mathrm{SD}$ or as median (range) when not normally distributed. The Kruskal-Wallis test was used to compare groups. Bonferroni's adjustment for multiple comparisons was applied. Spearman's correlation coefficients are reported. 
Table 1. Clinical characteristics and metabolic parameters of patients with Type 1 (insulin-dependent) diabetes mellitus without (DNP - ) or with nephropathy (DNP +) and non-diabetic patients with other renal diseases (RD)

\begin{tabular}{llll}
\hline & DNP - & $\mathrm{DNP}+$ & $\mathrm{RD}$ \\
\hline Number $(\mathrm{M} / \mathrm{F})$ & $18(8 / 10)$ & $33(19 / 14)$ & $42(26 / 16)$ \\
Age $($ years) & $45 \pm 8$ & $37 \pm 11^{\text {a }}$ & $44 \pm 15$ \\
Diabetes duration (years) & $27 \pm 9$ & $25 \pm 8$ & - \\
(range) & $(18-44)$ & $(10-37)$ & \\
HbA $_{\mathrm{Ic}}(\%)$ & $9.0 \pm 1.2$ & $9.0 \pm 0.7$ & - \\
AER $(\mu \mathrm{g} / \mathrm{min})$ & $7(3-19)$ & $271(30-2846)$ & - \\
Creatinine $(\mu$ mol/l) & $83 \pm 12$ & $106 \pm 41^{\mathrm{b}}$ & $399 \pm 286^{\mathrm{c}}$ \\
Protein/creatinine & - & - & 2.6 \\
ratio $(\mathrm{g} / \mathrm{mmol} \times 10)$ & & & $(0.1-19.7)$ \\
MAP (mm Hg) & $93 \pm 6$ & $101 \pm 10^{\mathrm{d}}$ & $107 \pm 11^{\mathrm{e}}$ \\
Hypertension $(n)$ & 0 & 15 & 24 \\
\hline
\end{tabular}

$p<0.02$ compared to DNP - and RD;

b $p<0.05$ compared to DNP - ;

c $p<0.001$ compared to DNP - and DNP + ;

d $p<0.001$ compared to DNP - ;

e $p<0.02$ compared to DNP + and DNP -

AER - albumin excretion rate;

MAP - mean arterial blood pressure

\section{Results}

Clinical data of the patients are given in Table 1. The two groups with diabetes mellitus did not differ with respect to duration of diabetes or $\mathrm{HbA}_{1 c}$. The patients with diabetic nephropathy were significantly younger than the patients without nephropathy $(p<0.01)$. In the patients with diabetic nephropathy serum creatinine and MAP were significantly higher $(p<0.05$ and $p<0.001)$ compared to the diabetic patients without nephropathy. Of the 33 patients with diabetic nephropathy 11 had incipient nephropathy (AER 20-200 $\mu \mathrm{g} / \mathrm{min}$ ) whereas 22 had overt nephropathy (AER $>200 \mu \mathrm{g} / \mathrm{min}$ ). The hypertensive patients in this group $(n=15)$ all had overt nephropathy. In the patients with renal disease the underlying renal disease was glomerular in origin in 26 patients and nonglomerular in 16 patients. NaLiCT levels in the three patient groups are shown in Figure 1. All three groups had elevated levels of $\mathrm{NaLiCT}$ compared to healthy subjects (median 244; range 134-390 $\mu \mathrm{mol} \cdot \mathrm{l} \mathrm{cells}^{-1} \cdot \mathrm{h}^{-1}$ ), however, no significant differences were found between the patient groups. Median values were 321 (189-627) $\mu \mathrm{mol} \cdot 1 \mathrm{cells}^{-1} \cdot \mathrm{h}^{-1}$ for the diabetic patients without nephropathy, 322 (162-676) in the diabetic patients with nephropathy and 300 (142-655) in the patients with other renal diseases. Furthermore, values of patients with incipient nephropathy did not differ from values in patients with overt nephropathy (284 (217-649) vs 344 (162-676) $\mu \mathrm{mol} \cdot 1$ cells $\left.^{-1} \cdot \mathrm{h}^{-1}\right)$. Values above the upper limit of nor$\mathrm{mal}\left(400 \mu \mathrm{mol} \cdot \mathrm{I} \mathrm{cells}^{-1} \cdot \mathrm{h}^{-1}\right)$ were found in 5 of $18(28 \%)$, 10 of $33(30 \%)$ and 10 of $42(24 \%)$ of the groups 1,2 and 3 , respectively $(p=\mathrm{NS})$. No correlations were found between $\mathrm{NaLiCT}$ and age, $\mathrm{HbA}_{1 \mathrm{c}}$, creatinine, AER and body weight.

\section{Discussion}

We did not find increased levels of NaLiCT in patients with diabetic nephropathy compared to patients without diabetic nephropathy or patients with other renal diseases. Our observations are in contrast to the results reported by Mangili et al. [4] and Krolewski et al. [3]. There are no obvious explanations for this difference. Theoretically, differences in methods of NaLiCT measurement could be responsible. Our patients were not studied in the fasting state and we used $\mathrm{LiHCO}_{3}$ instead of $\mathrm{LiCl}$ for loading of the erythrocytes with lithium. We do not believe that differences in methodology explain the differences in results. First, we were sure to achieve intracellular lithium concentrations above the maximum transport capacity. Secondly, our results in normal volunteers are similar to those reported by Mangili et al. [4] and Carr et al. [8]. Thirdly, we have compared both methods of measurement of $\mathrm{NaLiCT}$ in six healthy subjects and found no differences (mean with $\mathrm{LiHCO}_{3}: 266 \pm 63 \mu \mathrm{mol} \cdot 1$ cells $^{-1}$. $\mathrm{h}^{-1}$; mean with $\mathrm{LiCl} 254 \pm 66$; mean difference $17 \pm 9$; NS) Lastly, it has been reported that a light breakfast does not influence NaLiCT [9].

If we analyse the different studies and calculate in the various patient groups the proportion of patients with NaLiCT above $400 \mu \mathrm{mol} \cdot 1 \mathrm{cells}^{-1} \cdot \mathbf{h}^{-1}$ (the upper limit in healthy subjects $[4,8$, this study]) a similar distribution is found for patients without diabetic nephropathy: $15 \%$ [4]; $36 \%$ and $40 \%$ [3];33\% [8] and $28 \%$ (this study). This similarity is also found for patients with non-diabetic renal disease: $27 \%[4]$ and $24 \%$ (this study). A major difference is only observed for patients with diabetic nephropathy: respectively $87 \%$ [4],60\% [3] and 30\% (this study). It should be realized that exogenous factors can influence NaLiCT, especially abnormal lipid profiles [10]. Noticeably, the patients with diabetic nephropathy in the studies of Mangili et al. [4] and Krolewski et al. [3] had respectively a higher degree of proteinuria and a higher level of $\mathrm{HbA}_{1 \mathrm{c}}$, factors which could have influenced plasma lipids. Further

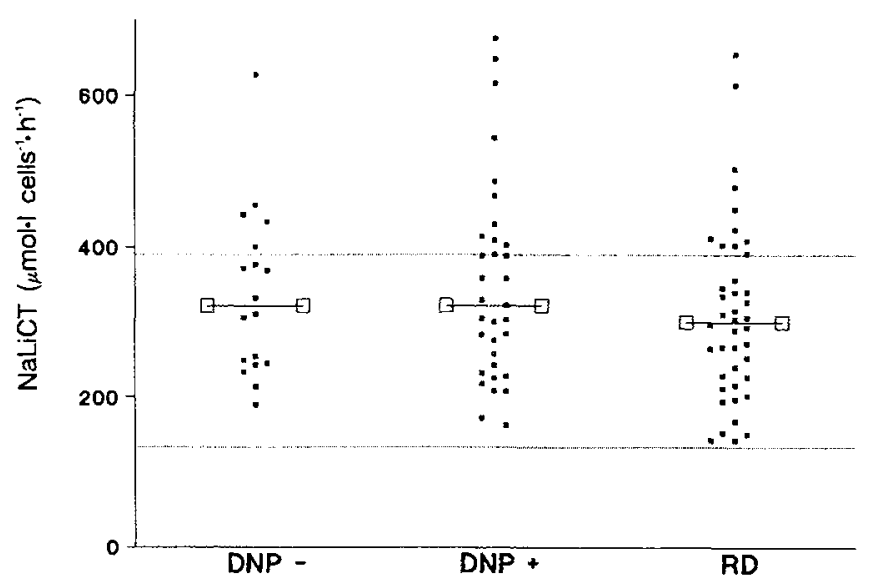

Fig.1. Individual and median values of sodium-lithium countertransport ( $\mathrm{NaLiCT}$ ) of Type 1 (insulin-dependent) diabetic patients without (DNP - ) and patients with nephropathy (DNP + ) and patients with non-diabetic renal disease (RD). The upper and lower limits of NaLiCT in healthy control subjects are indicated by dotted lines 
studies are needed to clarify which exogenous factors can influence NaLiCT and could have biased the resuits of the studies. In conclusion, we could not confirm that NaLiCT is increased in patients with diabetic nephropathy. Therefore, $\mathrm{NaLiCT}$ cannot be used as a marker for diabetic nephropathy.

Acknowledgements. We gratefully acknowledge the help of Prof. J.J.H.H. M. de Pont Ph. D., Mr. H. Swarts and Mr. B. Roszek of the Department of Biochemistry, University of Nijmegen, for development of the sodium-lithium countertransport-assay and the staff of the Laboratory of Clinical Chemistry especially J.C.M.Hafkenscheid Ph.D., Mrs. A. School and Mrs. M. Hessels who performed the sodium-lithium countertransport measurements for this study. The study was supported by a grant from the Dutch Kidney Foundation $(87.0688)$

\section{References}

1. Canessa M, Adragna N, Solomon HS, Connolly TM, Tosteson DC (1980) Increased sodium-lithium countertransport in red cells of patients with essential hypertension. N Engl J Med 302: $772-776$

2. Viberti GC, Keen H, Wiseman MJ (1987) Raised arterial pressure in parents of proteinuric insulin dependent diabetics. $\mathrm{Br}$ Med J 295: 515-517?

3. Krolewski AS, Canessa M, Warram JM, Laffel LMB, Christlieb AR, Knowler WC, Rand LI (1988) Predisposition to hypertension and susceptibility to renal disease in insulin-dependent diabetes mellitus. N Engl J Med 318: 140-145

4. Mangili R, Bending JJ, Scott G, Li LK, Gupta A, Viberti GC (1988) Increased sodium-lithium countertransport activity in red cells of patients with insulin-dependent diabetes and nephropathy. N Engl J Med 318: 146-150

5. Ibsen KK, Jensen HA, Wieth JO, Funder J (1982) Essential hypertension: sodium-lithium countertransport in erythrocytes from patients and from children having one hypertensive parent. Hypertension 4: 703-709

6. Elving LD, Bakkeren JAJM, Jansen MJH, de Kat Angelino CM, de Nobel E, van Munster PJJ (1989) Screening for microalbuminuria in patients with diabetes mellitus: frozen storage of urine samples decreases their albumin content. Clin Chem 35: 308-310

7. Ginsberg JM, Chang BS, Matarese RA, Garella S (1983) Use of single voided urine samples to estimate quantitative proteinuria. N Engl J Med 309: 1543-1546

8. Carr S, Mbanya JC, Thomas T, Keavey P, Taylor R, Alberti KGMM, Wilkinson R (1990) Increase in glomeralar filtration tate in patients with insulin-dependent diabetes and elevated erythrocyte sodium-lithium countertransport. N Engl J Med 322: $500-505$

9. Trevisan M, Ostrow D, Cooper R, Liu K, Sparks S, Stamler J (1981) Methodological assessment of assays for red cell sodium concentration and sodium-dependent lithium efflux. Clin Chim Acta 116: 319-329

10. Carr SJ, Thomas TH, Laker MF, Wilkinson R (1989) Elevated sodium-lithium countertransport: a familial marker of hyperlipidaemia and hypertension? J Hypertens 8: 139-146

Received: 25 June 1990

and in revised form: 1 October 1990

L. D. Elving, M. D.

Department of Medicine

Division of General Internal Medicine

University Hospital

P.O. Box 9101.

NL-6500 HB Nijmegen

The Netherlands 